\title{
Value of forest berries and mushrooms picking in Slovakia's forests
}

\author{
M. Kovalčík
}

National Forest Centre, T.G. Masaryka 22, 96092 Zvolen, Slovakia, E-mail:kovalcik@nlcsk.org

\begin{abstract}
Kovalčík, M. 2014: Value of forest berries and mushrooms picking in Slovakia as an ecosystem service of mountain forests. - Beskydy, 7 (1):39-46

Non-wood forest products have important commercial, environmental, social and recreational roles in many European forests. Collecting wild foods from the forests now largely represents a form of recreation. In some countries, any revenues from the sale of wild food are exempted from income tax. The main objective of this work is to estimate the value of the selected forest berries and mushroom picking in Slovak forests. A random sample of 5,168 Slovak inhabitants was surveyed, with 1,534 interviews in 2006, 1,732 interviews in 2007, 1,402 interviews in 2008 and with 500 interviews in 2011. Face to face interviews were used and people were asked to answer prefilled questions. Based on the results of the survey, the most collected forest berry is blueberry (Vaccinium myrtillus), one third of respondents stated, that they picked them either for own consumption or for sale. Harvest activity in mushrooms picking is connected mainly with Boletus sp. They were picked by two-thirds of respondents for own consumption and by $2 \%$ for sale. Mushrooms picking implies revenues of around 110-140 mil $€$ annually. Levels of activity differed in each year. It can be influenced also by poorer crop in some years. In general, average price was higher in years with lower harvest.
\end{abstract}

Key words: non-wood forest products, forest berries and mushroom

\section{Introduction}

During last sixty years, the countries of Central and Eastern Europe have experienced two profound changes in the dominant political ideology; a transition to socialist centrally planned economy during the early 1950's followed by a transition back to the market economy in the years following 1989 (Dale, Baldwin 1999). After the year 1989, there occurred a shift in the perception of forest functions from the strictly productive character to the acknowledgement of its other functions (recreational and environmental). Significant changes in forest management and organizational structure took place as well. Forestry after 1989 can be characterized by decrease in the number of employees, longlasting wage disparity in comparison with other economic sectors, reduction of state funding of the performances in public interest, increase of wood deliveries, progressive stabilization of wood export, preparation for EU accession and the link-up to the Common Agricultural Policy. These changes had great impact on socioeconomic and legal framework and brought changes in forestry sector as well. Recreational use of forests has increased considerably as well as picking of forest berries and mushrooms as a significant source of income. Many people go mushroom picking in the forests as a recreational activity and some also sell the mushrooms they collect in local markets (de Aragon et al. 2011).

The world's total forest area is just over 4 billion hectares and forests cover 31 percent of total land area (GFRA 2010). With $41 \%$ of forest area, Slovakia is above the world's average and belongs to the most forested countries in Europe. Most of forests in Slovakia are located in mountain regions. Forests have a potential to provide the society with a number of different ecosystem services as well as non-wood products. 
Non-wood forest products have important commercial, environmental, social and recreational roles in many European forests. Nonwood forest products are of "biological origin other than wood derived from forests, other wooded land and trees outside forests" (FAO 1999). Examples include mushrooms, berries cork, nuts, acorns and other tree berries, resin, medicinal and aromatic plants, honey etc. They represent a significant source of income in several European regions. In some forests, the market value of wild mushrooms may well be as high as that of timber (Pettenella, Secco 2006). Collecting wild foods from the forests now largely represents a form of recreation. In some countries, any revenues from the sale of wild food are exempted from income tax. On other side, the influx of pickers to forests generates an environmental impact cost. When access to the forests is free and when the property rights to the products that can be picked from the ground are not clearly assigned, forest owners bear a cost in the form of forest damage by pickers, and receive no benefit. Pickers can have a negative impact by overharvesting the berries and mushrooms or by damaging the habitat, e.g. compacting the soil and impairing its quality. These forest owners therefore have little incentive to provide the public with more of better forests, however socially desirable this would be. If the value of this environment service to society was known, an appropriate policy could be applied. Estimating environmental benefits can help in this regard (de Aragon et al. 2011). Non-wood forest products valuation and factors effecting their provision are topics of research in many countries (e.g. Cibulka et al. 1996, Šišák 1997, 1998, 2000, 2006, Šišák et al. 1997, Saastamoinen, Kangas, Aho 2000, Barszcz, Šišák 2003; Pettenella, Secco 2006, Kovalčík, Tutka 2008, 2009; Illukpitiya, Yanagida 2008; Šišák, Pulkrab 2009, Shediac et al. 2008, de Aragón et al. 2011, Cai et al. 2011, Mavsar et al. 2012).

Actual provision of non-wood products and services depends upon the demand expressed by different stakeholder groups. To define the importance of specific services, interaction with stakeholder groups is one of the key features. In case of large stakeholder groups, like the general public, opinion pools can be used to obtain the information needed to valuate these services (Mavsar et al. 2012). The main objective of this work is to estimate the value of the selected forest berries and mushroom picking in Slovak forests and its contribution to quality of life, mostly in rural areas.

\section{Material and methods}

In order to estimate the quantity and value of forest berries and mushroom picking, a survey was conducted. Interviews were provided by professional pooling agency and trained students and face to face interviews were used as a research method. Questions focused on forest berries (blueberry - Vaccinium myrtillus, cranberry - Vaccinium vitis-idaea, raspberry - Rubus idaeus, blackberry - Rubus fruticosus, elderberry Sambucus nigra and juniper - Juniperus communis) and mushrooms (boletus - Boletus edulis and Boletus sp., chestnut boletus - Leccinus sp., russula - Russula sp., boletellus - Xerocomus sp., chanterelle - Cantharellus cibarius, honey agaric - Macrolepiota sp.) picking for own consumption and for sale were a part of the used questionnaire. List of species was open, so respondents could indicate also other species they collected. In addition, information on the commercial prices at which the forest berries and mushrooms were traded, was collected. The selling prices were used for estimating the value of forest berries and mushrooms for own consumption.

A random sample of 5,168 Slovak inhabitants was surveyed, with 1,534 interviews in 2006, 1,732 interviews in 2007, 1,402 interviews in 2008 and with 500 interviews in 2011. Face to face interviews were used and people were asked to answer prefilled questions. In this way, also non-pickers are included in the sample. The surveys were conducted after the course of the season, which lasts approximately from June to October. Sample of persons older than 14 was the target group of the survey. Based on consultations with professional pooling agency, the sample was chosen so as to be representative of the Slovakian population in terms of age and gender (Kovalčík, Tutka 2008, 2009). Average age of the sample was 39 years, which is comparable to average age of Slovak inhabitants, which is 38 years (Statistical Office of the Slovak republic). The gender structure of sample is comparable to Slovak average; men little bit dominate in the sample. Respondents from north and middle Slovakia dominated in the sample (more than $50 \%)$, but respondents came from all districts. Age structure and gender proportion of the sampled population are not statistically different from those of the Slovak population older than 14 years. 


\section{Results}

\section{Forest berries picking}

Based on the results of the survey, the most collected forest berry is blueberry (Vaccinium myrtillus), 34\% of respondents in 2006 and approximately $25 \%$ in 2007, 2008 and 2011 stated, that they picked them either for own consumption or for sale. Mean harvest in 2006 was $2.8 \mathrm{~kg}$ per respondent and season. This implies revenues of around $6 €$ at 2006 sale prices. Mean harvest was lower in the next years, $1.89 \mathrm{~kg}$ per respondent and season in 2007, $1.71 \mathrm{~kg}$ per respondent and season in 2008 and $0.61 \mathrm{~kg}$ per respondent and season in 2011. Levels of activity differed in each years. It can be influenced also by poorer crop in some years. In general, average price was higher in years with lower harvest. Similar development can be seen at other forest berries. Mean harvest and average prices for all investigated forest berries are presented in table 1.

\section{Forest mushrooms picking}

Harvest activity in mushrooms picking is connected mainly with Boletus sp. They were picked by two-thirds of respondents for own consumption and by $2 \%$ for sale. Mean harvest was $3.51 \mathrm{~kg}$ per respondent and season in 2006, respectively $3.23 \mathrm{~kg}$ per respondent in 2007. Mean harvest was lower in the next years, $1.90 \mathrm{~kg}$ per respondent and season in 2008 and $1.15 \mathrm{~kg}$ per respondent and season in 2011. Similar results were in mushrooms picking for sale Mean values were 0.22 and $0.27 \mathrm{~kg}$ per respondent in 2006 and 2007 and lower in 2008 and 2011 in the amount 0.11 , resp. $0.08 \mathrm{~kg}$ per respondent and season. Levels of activity differed in each years. It can be influenced also by poorer crop in some years. Mean harvest and average prices for all investigated forest mushrooms are presented in table 2 .

\section{Value of forest berries and mushrooms picking}

Average value of berries and mushrooms, mean harvest per person and season and number of Slovak inhabitants older than 14 years were used to calculate value of forest berries and mushrooms picking. On average, 19,601 metric tons of berries was collected every season, with a maximum of 29,042 tons in 2006; and 27,488 metric tons of forest mushrooms, with a maximum of 34,126 tons in 2006. It implies mean value of forest berries in the amount of $47.7 \mathrm{mil}$ $€$, with a maximum of 60.1 mil $€$ in 2008 . And mean value of forest mushrooms in amount of 27.5 mil $€$, with a maximum of 95.0 mil $€$ in 2007 (Tab. 3). Disparity in single years is due to the annual differences in production.

\section{Discussion and conclusions}

Information on value of the main forest berries and mushroom picking in Slovak forests and its contribution to quality of life mostly in rural areas were received by the survey. Collectable natural products such as wild berries and mushrooms are important and valuable ecosystem goods in Slovak forests as well as in other countries. For example, in Finland 40-50 million $\mathrm{kg}$ of cranberries (Vaccinium vitis-idaea) and blueberries (Vaccinium myrtillus) is collected annually. The total annual value of the harvested wild berry crop can be more than 100 million $€$ (Saastamoinen, Kangas, Aho 2000). Moreover, the economic value of annual forest berries and mushroom production can easily exceed the value of annual timber production in some forests. Total value of forest berries and mushrooms picking is in the amount of 140 million $€$, except of 2011. Compared to total wood income of Slovak forestry, which were in 2006-2011 in the amount of 384 million $€$ (Moravčík et al. 2010, Moravčík et al. 2009, Moravčík et al. 2006), it is little more than one third of the value of wood sales in this period.

Forest managers and researchers in several countries have reported that pickers are unwilling to share information about their activities because of a combination of jealously guarding good sites, awareness that they access the resource without a required authorization and worries about possible changes in wild berries and mushrooms regulations. Under the socalled every-man's right, anyone is entitled to collect wild foods from a forest for own consuption, irrespective of land ownership (Cai et al. 2011). This fact influenced results of the survey, mainly the data on picking of forest berries and mushroom for sale, where many respondents filled in nothing, or underestimated their collected amount. Just about 1\% of pickers appeared to be gathering forest berries and mushrooms for sale. Although the survey produced evidence that for a significant group of people, the picking of forest berries and mushroom can generate the possibility of significant additional income.

Diversified forest economy, which is based on a wide range of profitable products, plays a key role in sustainable forest management. There is a link between economic diversity and sustainability. Economic diversification can reduce national economic volatility and increase its real activity performance (Shediac et al. 2008). A challenge for diversification of activities brings new possibilities of income for rural areas. Farming and forestry businesses represent 

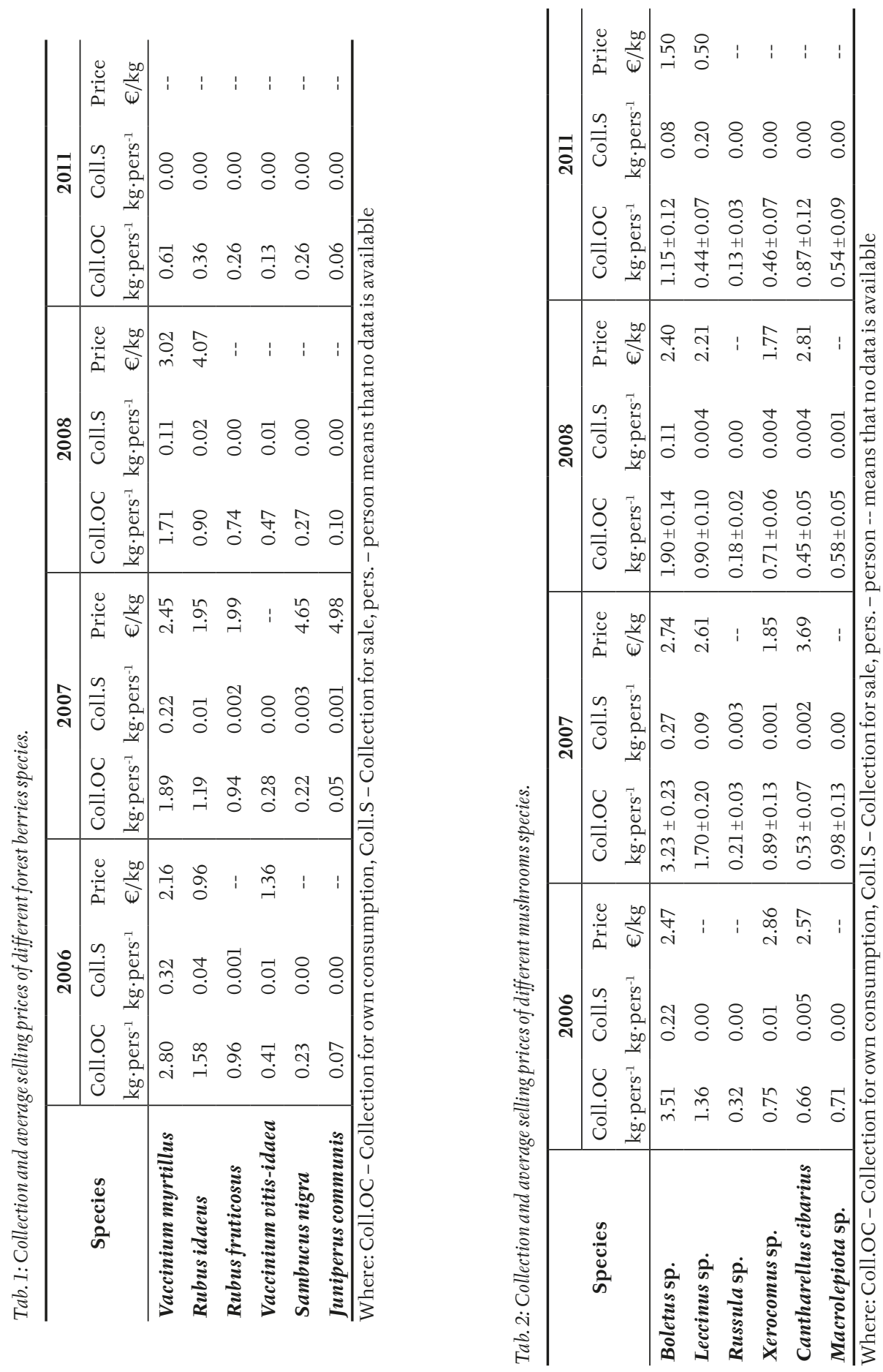
Tab. 3: Total value of forest berries and mushrooms collection.

\begin{tabular}{lrrrr}
\hline \multicolumn{1}{c}{ Indicator } & $\mathbf{2 0 0 6}$ & $\mathbf{2 0 0 7}$ & $\mathbf{2 0 0 8}$ & $\mathbf{2 0 1 1}$ \\
\hline Forest berries & & & & \\
\hline Own consumption & 51.8 & 47.7 & 58.1 & 25.2 \\
Sale & 3.4 & 2.7 & 2.0 & \\
Total & 55.2 & 50.4 & 60.1 & 25.2 \\
\hline \multicolumn{1}{l}{ Forest mushrooms } & & & \\
\hline Own consumption & 82.7 & 90.5 & 49.1 & 28.4 \\
Sale & 2.7 & 4.5 & 1.4 & 1.0 \\
Total & 85.4 & 95.0 & 50.5 & 29.4 \\
\hline Forest berries and mushrooms & 140.6 & 145.4 & 110.6 & 54.6 \\
\hline
\end{tabular}

primary sector in rural areas. They give essential raw materials and provide a place of beauty, rest and recreation. The challenge for diversification is about meeting the possibilities and unlocking the potential. Forestry along with traditional income source from wood must develop new products and services. On the other hand, it has a great deal to offer them. Diversification of forestry and non-forestry activities as well as activities carried out in the framework of related sectors must be aimed at the increase of employment and incomes. Income diversification helps to maintain sustainable forest management and, as it is presented by Illukpitiya, Yanagida (2008), reducing forest dependence contributes to the conservation of biodiversity and thus to conservation of forest resources.

Information on total annual value of the harvested forest berries and mushroom should be used for formulation of forestry policy targets in Slovakia. Priority areas defined in Slovak forest policy (e.g. National Forest Programme for Slovakia, Forestry Development Strategy etc.) are tourism (forest tourism, education, tourist guide, hunting), energy (use of alternative energy sources - bio energy, water) and the environment (environmental services in protection and enhancement of biodiversity). Diversification of production activities means their extension beyond the forestry in the areas of non-traditional wooden products, growing of ornamental trees and bushes, Christmas trees, medicinal plants, etc.

\section{Acknowledgment}

This publication is the result of the project implementation: Extension of the Centre of Excellence "Adaptive Forest Ecosystems", ITMS: 26220120049 , supported by the Research \&
Development Operational Programme funded by the ERDF. The authors would like to acknowledge the valuable comments provided by the reviewer of this manuscript, which led to substantial improvement of the paper.

\section{References}

BARsZCZ, A., ŠIšÁK, L. 2003: Udostepnenie lasów do zbioru plodów runa lešnego $\mathrm{v}$ šwietle przepisów i zwyczajów niektórych krajów Europy. Forest availability for the harvesting of forest by-products in the light of regulations and traditions of the selected European countries. Sylwan, 3: 89-93.

Cai, M., Pettenella, D., Vidale, E. 2011: Income generation from wild mushrooms in marginal rural areas. Forest Policy and Economics, 13: 221-226.

CibulKa, J., ŠišĀK, L., Pulkrab, K., Miholová, D. 1996: Cadmium, lead, mercury and caesium levels in wild mushrooms and forest berries from different localities of the Czech Republic. Scientia Agriculturae Bohemica, 27 (2): 113-129.

Dale, P., Baldwin, R. 1999: Emerging land markets in Central and Eastern Europe, In.: Structural change in the farming sector of Central Eastern Europe, Second EU accession workshop in the rural sector, Warsaw Poland, World bank technical paper No. 465, 81-109 pp., available at http://books.google. com/books?hl=sk\&lr=\&id=-MqOLgYOFsE $\mathrm{C} \&$ oi=fnd\&pg=PA81\&dq=land+restitution + process + in + the + forest + sector $\&$ ot $s=v X W$ U2AKNqK\&sig=YJ8dNMeLUIo2obBijsM

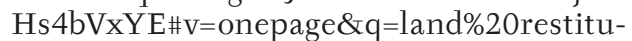
tion\%20process\%20in\%20the\%20forest $\% 20$ sector\& $\mathbf{f}=$ false, (accessed February 14, 2014) 
de Aragón, J.M., Riera, P., Giergiczny, M., ColiNAs, C. 2011: Value of wild mushrooms picking as an environmental service. Forest Policy and Economics, 13: 419-424.

European Commission, 2005: Council Regulation (EC) No 1698/2005, http://eur-lex.europa.eu/LexUriServ/LexUriServ.do?uri=O J:L:2005:277:0001:0040:EN:PDF, (accessed February 14, 2014).

Food and Agriculture Organization, 1999: Towards a harmonized definition of non-wood forest products. Unasylva, 50 (1999/3), Available at www.FAO.ORG/DOCREP/X2450E/ X2450E00.HTM. (accessed May 28, 2014).

GFRA 2010: Global Forest Resources Assessment Main report, FAO Forestry paper 163, Food and Agriculture Organization of the United Nations Rome, $378 \mathrm{~s}$.

ILLUKPITIYA, P., YANAGIDA, J.F. 2008: Role of income diversification in protecting natural forests: evidence from rural households in forest margins of Sri Lanka. Agroforestry Systems, Springer Netherlands, 74 (1): 51-62.

Kovalčík, M., TutKa, J. 2009: Hodnotenie rekreačnej funkcie lesov SR preferenčnými metódami [Valuation of the outdoor recreation in Slovakia by using preferences methods]. In: Aktuálne otázky ekonomiky lesného hospodárstva SR: Recenzovaný zborník z odborného seminára, Zvolen 21.-22. október 2009, Zvolen: Národné lesnícke centrum, 115-128.

Kovalčík, M., TutKa, J. 2008: Hodnotenie rekreačnej funkcie lesov SR preferenčnými metódami - výsledky testovacej štúdie [Valuation of the outdoor recreation in Slovakia by using preferences methods - results of testing study]. In: Aktuálne otázky ekonomiky LH SR: Zborník referátov z odborného seminára 10. december 2008, NLC Zvolen, s. 89-100.

Mavsar, R., Japejl, A., Kovač, M. 2012: Tradeoffs between fire prevention and provision of ecosystem services in Slovenia. Forest Policy and Economics, 29: 62-69.

MoravČík, M., Radocha, M., TutKa, J., KonôPKa, J., Kovalčík, M., Kunca, A., Longauerová, V., Marušáková, L'., Oravec, M., Sarvaš, M., SARVAŠOVÁ, Z., SCHWARZ, M., SUŠKovÁ, M., SVItoK, R., ŠEbeŇ, V., Zúbrik, M., Žiaková, M., OndRejČÁK, M., Toma, P., Dóczy, J., ŠimovÁ, K., Balkovič, J., GregušKa, B., ČıKovsKÝ, M. 2010: Správa o lesnom hospodárstve v Slovenskej republike za rok 2009 [Report on the Status of Forestry in Slovak Republic for 2009.] Zvolen and Bratislava, National Forest Centre and Ministry of Agriculture and Rural Development: 102.
Moravčík, M., KonôPKa, J., TutKa, J., Čaboun, V., Černota, M., Kovalčík, M., Kriššáková, I., Longauer, R., Macko, J., Marušáková, L'., Novotný, J., Oravec, M., Pavlenda, P., Priwitzer, T., Radocha, M., Sarvaš, M., Sarvašová, Z., Schwarz, M., Siaked, P., SušKová, M., SviTOK, R., ŠEbeŇ, V., ŠTefančíK, I., TuČEKovÁ, A., Žiaková, M., OndrejčÁk, M., Toma, P., Hulman, P., Šimová, K., Balkovič, J., GregušKa, B., Dóczy, J., Lajda, Z., HušŤaková, M. 2009: Správa o lesnom hospodárstve v Slovenskej republike 2009 [Report on the Status of Forestry in Slovak Republic 2009.] Zvolen, National Forest Centre: 147.

MoravČír, M., KonôpKa, J., TutKa, J., Ďurkovič, J., KonôPKa, B., KovalČík, M., MinĎÁš, J., Novotný, J., Oravec, M., Pavlenda, P., Petrášová, V., Radocha, M., Sarvašová, Z., SuŠKovÁ, M., SVITOK, R., ŠEBEŇ, V., ŽIAKOVÁ, M., ONDREJČÁK, M., Toma, P., Greppel, E., Bútor, P., Hulman, P., Šimová, K., BALKovič, J., LÁszLÓ, P., GregušKa, B. 2006: Správa o lesnom hospodárstve v Slovenskej republike 2006 [Report on the Status of Forestry in Slovak Republic 2006.] Zvolen, National Forest Centre: 144.

Pettenella, D., Secco, L. 2006: Small-scale forestry in the Italian Alps: frommassmarket to territorial marketing. In: Wall, S. (Ed.): Small-scale forestry and rural development. The intersection of ecosystems, economics and society. Proceedings of IUFRO 3.08 Conference, Galway, Galway-Mayo Institute of Technology. Galway-Mayo Institute of Technology, Galway, 398-408.

Saastamoinen, O., Kangas, K., Aho, H. 2000: The picking of wild berries in Finland in 1997 and 1998. Scandinavian Journal of Forest Research 15, 645-650.

Shediac, R., Abouchakra, R., Moujaes, Ch.N., NaJjar, M.R. 2008: Economic Diversification. The Road to Sustainable Development. 20 pp. Booz \& Company Inc., Available at http:// www.booz.com/media/uploads/EconomicDiversification.pdf, (accessed February 14, 2014).

ŠIŠÁK, L. 1997: Význam produkce lesa kromě dřeva v České republice. Lesnictví-Forestry, 43 (2): 49-66.

ŠIŠÁK, L. 1998: Socio-economic importance of main non-wood forest products in the Czech Republic. Lesnictvi-Forestry, 44 (12): 542-548.

ŠIšÁK, L. 2000: Importance of the main nontimber forest products in the Czech Republic in 1998. Journal of Forest Science, 46 (7): 331-339. 
ŠIŠÁK, L. 2006: Importance of non-wood forest product collection and use for inhabitants in the Czech Republic. Journal of Forest Science, 52 (9): 417-426.

ŠišÁK, L., PulKRab, K. 2009: Společenská významnost produkce a sbèru netržnich lesnich plodin $v$ České republice. Patnáct let systematického sledování. Grada Publishing, a.s. Praha, 112 s.

ŠišÁk, L., Pulkrab, K., Kalivoda, V. 1997: Význam návštěvnosti lesa a sběru hlavních lesních plodin obyvateli území s lesy výrazně postiženými imisemi. Lesnictví-Forestry, 43 (6): 245-258. 
